\title{
Indung Art Work in Connectedness
}

\author{
Rini Maulina ${ }^{1}$ Setiawan Sabana ${ }^{2}$ Nuning Yanti Damayanti ${ }^{3}$
}

\author{
${ }^{123}$ Doctoral Program of Visual Art and Design, Faculty of Art and Design, Institut Teknologi Bandung, Bandung, \\ Indonesia \\ *Corresponding author.Email: rini.maulina@email.unikom.ac.id
}

\begin{abstract}
The fourth industrial revolution is the era of connectedness where information technology connects societies in the world. The Internet as a technology innovation maintains the world connected to become a "placeless connectivity". It also makes people more dependent on information technology, connectivity, and its advantages, and, as a result they need to stay connected to the network. In daily life, people commonly used internet-based systems, for example, e-government, e-commerce, e-education, e-medicine, e-laboratory, etc. Moreover, the Internet helps artists present their artworks to societies through an online exhibition in e-gallery. This study is about the creation of research-based artworks in the form of Indung with the Sundanese culture. The artworks represent the value of culture combined with contemporary works. By utilizing the internet network, the works are then presented in websites and social media, namely Instagram and YouTube. In this study, Art-Based Research was used to create the literature-based artworks, and to find the meaning of Indung, observations and interviews were conducted. This study focused on presenting Indung as an artwork to societies using websites and social media
\end{abstract}

Keywords: Art, Culture, Connectedness, Indung, Sundanese, 4.0

\section{INTRODUCTION}

Civilization is built by humans with values, social order, cultural arts, and the construction of physical, scientific, and technological facilities. Regarding this, Toynbee said "civilization is a culture that has reached a higher level of technological development [1]. Throughout the world civilization, information technology has been used. The discovery and use of the world's first books are information dissemination technology as the beginning of the development of sophisticated information technology, and then followed by forms of electronics, telegrams, radio, telephone, television, computers, satellites, and the internet. In further life, the use of internet networks in online communication and information affects the way of people who experience the Industrial Revolution 4.0 or the era of connectedness.

Information technology in the 4.0 era connects humans instantly with the world; its ease and speed make people in the information age highly dependent on online information. Piliang [2] states "the development of information technology, especially the internet, has raised the need for a real time lifestyle, a pattern that requires everything to be done through virtual channels,

carried out in" instantaneous" ways. The use of smartphones in the era of connectedness or information era 4.0 becomes a basic need, continuous information processing, connected with information and communication networks to carry out social, political, economic, art, and cultural activities. Those can be done by viewing news on web pages, shopping online, uploading videos on YouTube channels, socializing through social media such as Facebook, Instagram, and Twitter, writing and answering emails, uploading and downloading data from drive or cloud, and so on.

The existence of information technology in relation to the process of art, especially visual arts, is a central means to facilitate the ongoing visual arts. Information technology that triggers a change in the visual arts and culture of a nation, and creates a new society encourages the dynamics of art and culture. Also, the technology with digital features that use images, visualization, speed of access, global connectivity is able to facilitate the openness of a visual art and culture that can create opportunities to revitalize the potential of visual and cultural arts to become larger and easier to do. Likewise, with exploratory efforts for cultural values and uniqueness that are maintained for visual art, it can be used as a medium to explore, enhance, expose, and promote, as stated by Sugiharto [3].

The use of information technology has been carried out in the contemporary art field. Artists are well aware of the use of online information to publicize or promote art activities carried out to the general public more easily and more quickly. There have been many artists who manage personal web pages used as e-studios or egalleries [4]. It is like e-studios or galleries owned by 
famous artists Eko Nugroho and Heri Dono who have a web page http://ekonugroho.or.id/ and http://heridono.com/. Public can appreciate the artworks, artist profiles, artists' art activities through their smartphones or computers.

Conventional galleries have long been used as a means to display art works as an effort to disseminate information to the general public, but the common problem is the relatively low number of visitors; they only come during exhibitions, while the exhibition in a certain period of time has a low number of visitors. Delivering messages contained in the artwork becomes difficult to be appreciated by the general public. In addition, visitors have limited time and money to visit galleries; Indonesian people generally are not into art, so that they are reluctant to visit galleries.

The use of information technology for artists in the 4.0 era is very significant. The era of connectedness must be explored by artists not only as a media to popularize themselves or to popularize their artwork, but also a means to convey messages contained in art. Irianto said that the most important thing of contemporary art works is what message the artist wishes to convey through his artwork to the public today [5]. Contemporary artists have a moral responsibility to the community through their artworks, so that the use of e gallery as a medium to convey messages can make it easier for artists to carry out their responsibilities, and for people to appreciate visual art.

Supporting this, Indung (mother) art in Sundanese culture is developed regarding visual art-based research findings. Indung artwork is made to express the message about the meaning of Indung and the philosophical content in it. The message about Indung through visual art is important to be known by new generation, for example, the meaning of Indung for Sabana is that She is a God's representative on earth [6]. According to Damayanti, Indung means 'liven up' [7]. Affection can animate humans and prevent hatred. Because of this, love, and affection should be possessed by everyone; with affection, human will respect each other. Indung philosophy must be understood by everyone; the message needs to be conveyed through Indung visual arts in Sundanese culture.

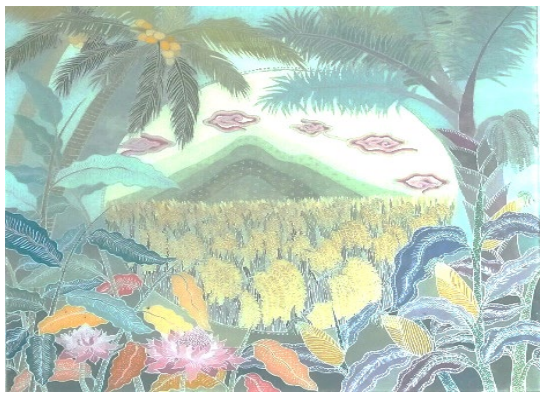

Figure 1 Rini, Maulina, "Ngabandungan Banda Indung" oil paint on glass, Cirebon glass painting techniques, $50 \times 50 \mathrm{~cm}$.
The use of information technology through web pages and social media for the dissemination of Indung visual art in Sundanese culture has become easier to do. It is done by placing the Indung visual art works created in the world of connectedness, so that they are easily accessible and appreciated by general public. Exploring the connectedness of the internet network by displaying online visual art works aims at disseminating Indungthemed visual arts in Sundanese culture to the society.

\section{METHOD}

This research used a descriptive method, and data collection in this study was carried out through observations, questionnaires, interviews, and library research. Observations were made to see the phenomenon of the use of web pages for e-galleries and studios. The questionnaire was employed to find out the general public opinions on Indung visual art works disseminated on web pages and social media, as well as to determine the impact of the media to introduce Indung art works to the community. Interviews were conducted with people who were competent in the field of visual arts to obtain their opinions on the artist responsibility and the meaning of Indung. The three speakers were visual art academician. Literature was used as a reference for theories related to the research conducted. Also, the dissemination of Indung-themed artworks in Sundanese culture used web pages and YouTube social media.

\section{FINDINGS AND DISCUSSION}

\subsection{Gallery in the era of Connectedness 4.0}

Since the mid1990s, the world has entered the era of information and communication technology (ICT); telephone and computer networks began to be used in human life as a means of communication and information. The world was formed by three waves of technological innovation, namely agricultural revolution, Industrial Revolution, and informational revolution as what is found in life today or a new way of life, as mentioned by Toffler in Webster [8]. The term industry 4.0, according to Vuksanović, Vešić and Davor [9], is defined as follows.

"The term Industry 4.0 means the smart factory in which smart digital devices are networked and they communicate with raw materials, semi-finished products, products, machines, tools, robots and men. This Industry is characterized by flexibility. Efficient use of resources and integration of customers and business partners in the business process". 
The industrial era 4.0 changes the industrial society into information society; the connectedness society is always related to communication and information networks. Various activities are carried out through the internet network; continuous information processing is the core of the information society life. The use of mobile devices creates new media such as social media, interactive media, digital television, online shops, and others. Advances in information technology affect changes in the way people live in carrying out activities in various fields of life such as economics, education, and art. Gizem Erboz, [10] states;

"Industry 4.0 deals with creating more digitized systems and network integration via smart systems. Through industry 4.0, smart systems would enable the replacement of the human-being in certain tasks and ease the working".

The industrial era 4.0 or allows artwork to be accessed more easily on web pages and social media through smart phones. Regarding the connectedness of the art field such as art performers, galleries, museums, and general public in industrial technology 4.0, Gere [11], states;

"How galleries and museums can engage with our increasingly technologized society, in particular the ubiquity of new media and new technologies such as the Internet, challenges to the art gallery or museum as an institution. At one level, these challenges are practical: how to take advantage of the new means of dissemination and communication these technologies make possible; how to compete as a medium for cultural practice in an increasingly media-saturated world; how to engage with new artistic practices made possible by such technologies, many of which present their own particular challenges in terms of acquisition, curation, and interpretation".

Today's artists can take advantage of the sophistication of information technology and the Internet for disseminating art on web pages, social media. https://whitecube.com/,https://studioegallery.net/,https:/ /artsandculture.google.com/, https://industryuk.online, www.asiancontemporaryart.com, https://indoartnow.co $\mathrm{m} /$, http://archive.ivaa-online.org/ are the examples of digital galleries (E Gallery) located outside and within the country. The purpose of utilizing information technology for e-gallery, according to Gere, is to disseminate and communicate art.

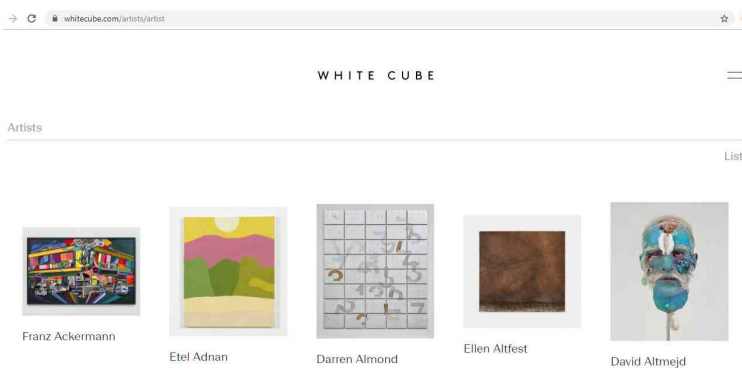

Figure 2 Landing Page of https://whitecube.com/

\subsection{Indung Art Works in the Era of Connectedness 4.0}

The creation of Indung-themed visual art works in Sundanese culture is developed through art-based research. The concept of Indung art works is an artist's interpretation of the meaning and philosophy of Sundanese culture [12]; the concept of art visualization refers to Peurseun's theory [13], namely visualization in the mythic, ontological, and functional areas. Visual art visualization adapts the identity of traditional visual art such as batik and Cirebon glass painting in the contemporary art resources. Heri Dono, Haryadi Suadi, and Radi Arwinda have explored traditional cultural characteristics in Indonesian contemporary art. The use of it is not much done by contemporary art; its purpose in Indung visual art is to show the identity of Indonesian visual arts, especially Sundanese culture [14]; related to this Irianto stated how the realm of tradition can provide enlightenment or as a message for the present generation [5].

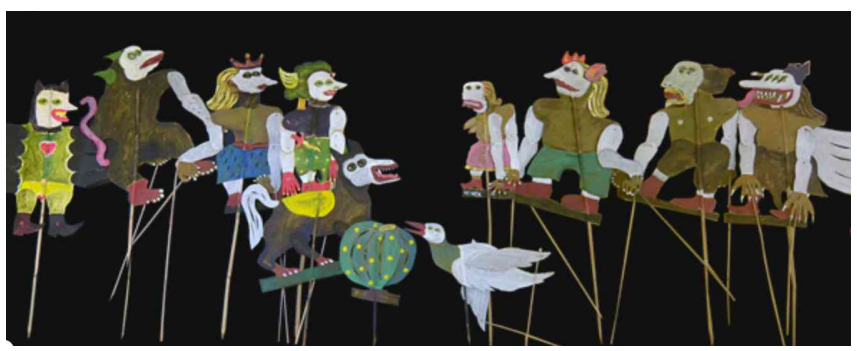

Figure 3 Heri Dono, "Momotaro" , cardboard, acrylic paint, bamboo, 1 set, 2015. Source: http://heridono.com/portfolio/2015/

Indung artwork has a message that should be conveyed to the general public. Artists have a responsibility to the public, through the artwork which has a social function of art. Concerning this, Feldman [15], states "in a certain sense, all works of art present a social function, because they are created for society. Feldman 
formulated the social functions of art; they are elaborated as follows: art affected the collective behavior of individuals; art was made to be displayed or used by the public; art explained the collective aspects of life which made the audience feel the participation in discussing the issue. Also on the reasons he made, many works of art are made to certainly bring an impact in any form. Feldman [15], stated that all art in his work presents social functions, bearing in mind the purpose of making it is to be presented in front of the audience. The process of creating a piece of art may indeed be based on personal values, but the social response from the public is expected.

Based on Feldman's statement, the dissemination of Indung art in Sundanese culture is important to do. In the industrial era 4.0 or the era of connectedness, dissemination through web pages and social media utilizes the advancement of information and connectivity technology today. Web pages and social media are used to facilitate artists in carrying out their social responsibilities, and making it easier for the public to access Indung's visual art in Sundanese culture. The use of information technology through smart phones and computers connected to the network will place the masterpieces of art in speed, immediacy, and connectedness. Indung visual art in Sundanese culture can be accessed on the web page https://www.artpal.com/rinimaulina and YouTube social media https://youtu.be/i8SCJiW4C-I.

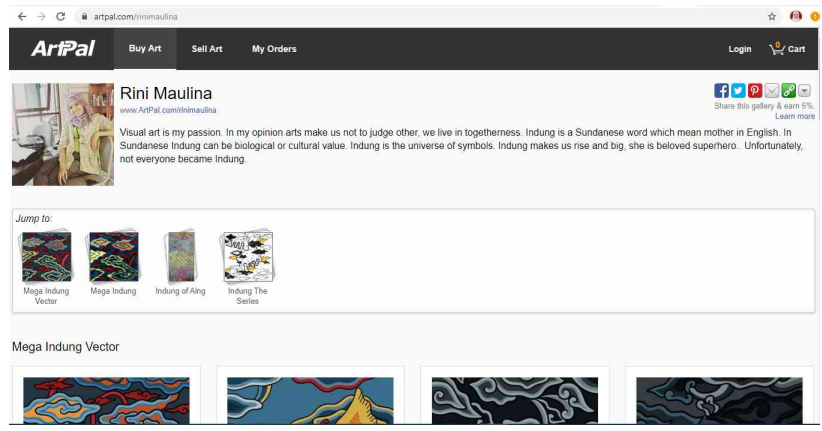

$\begin{array}{lllll}\text { Figure } & 4 & \text { Home } & \text { Page } & \text { from }\end{array}$ https://www.artpal.com/rinimaulina

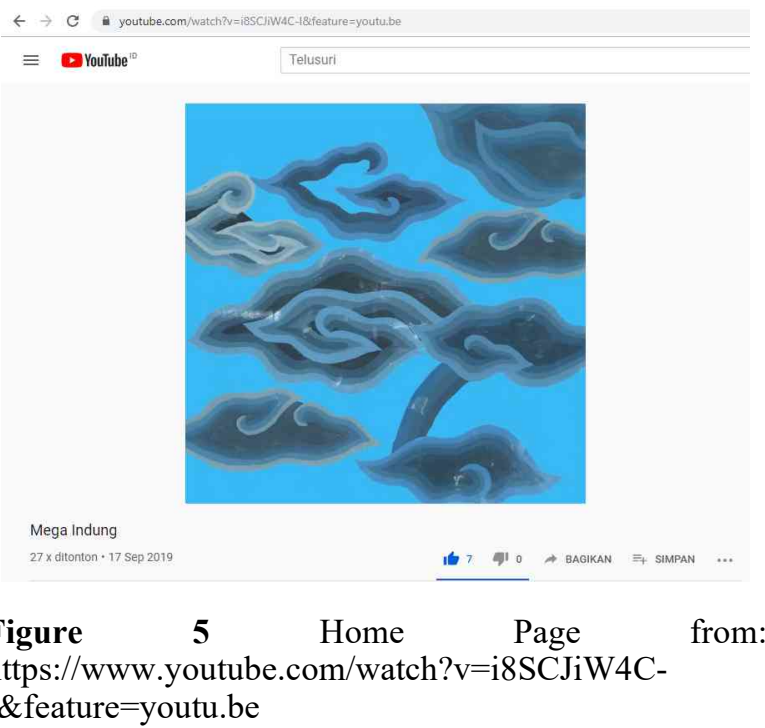

To find out the impact of the use of web pages and YouTube social media as an e-gallery of Indung visual art in Sundanese culture, the researchers distributed questionnaires to adults aged around 19-23 years (50 respondents). It is aimed at exploring opinions on the existence of e-galleries on web pages or YouTube. All respondents agreed that the e-gallery used by artists was needed to facilitate the public to see the artwork, to know the profile of the artist and artwork, and to connect artists with the public.

\section{CONCLUSION}

In the industrial era 4.0, the sophistication of information technology is an opportunity for artists to deal with connectivity which is beneficial as a manifestation of artists' accountability. The spread of social functions of art works created by artists can be realized. Artists in carrying out the responsibility of publishing their work to the general public have been facilitated by web pages and social media; this is in line with the Feldman's statement about the purpose of making art to be presented to the public. This is also in line with the Irianto's statement that artists convey messages through their art for the community.

The results of interviews with Sabana and Damayanti regarding the importance of the meaning of Indung are known by everyone, reinforcing the importance of Indung-themed visual art in Sundanese culture that has a content of meaning and philosophy conveyed to the Indonesian people.

By utilizing information technology advancements in the industrial era 4.0, the public can be educated by appreciating and learning artwork presented on web 
pages or social media. The results of the questionnaires show that all respondents agreed that the use of the web pages and YouTube for e-galleries is indispensable for the connectedness of artists, artworks, and the community. Artworks stored on web pages or on social media can be constantly accessed and connected to provide the social functions to the public.

\section{REFERENCES}

[1] Toynbee, Arnold. "The Disintegrations of Civilization”, New York, The Free Press, 1965

[2] Yasraf, Amir Piliang. "Dunia yang Dilipat: Tamasya Melampaui Batas-batas Kebudayaan [A Folded World: Sightseeing Beyond Cultural Boundaries]." Yogyakarta: Jalasutra (2004).

[3] Sugiharto. Bambang I, Kumpulan Materi Perkuliahan Filsafat Budaya [Teaching and Learning Materials Collection in Philosophy of Culture Subject], Bandung, Program Studi Doktor Ilmu Seni Rupa dan Desain, Institut Teknologi Bandung, 2019.

[4] Maulina, Rini, Setiawan Sabana, and Nuning Damayanti. "E Gallery untuk Pameran Daring Studi Kasus: Karya Seni Rupa Indung [E Gallery for Case Study Online Exhibitions: Indung Fine Art]." Sandyakala (2019): 230-239.

[5] Irianto, Asmudjo J. Wawancara [Interview]. 9 Sept. (2019). unpublished.

[6] Sabana, Setiawan. Wawancara [Interview]. 11 Des. (2019). unpublished.

[7] Damayanti, Nuning Yanti. Wawancara [Interview]. $13 \mathrm{Feb}$. (2019). unpublished

[8] Webster, "Theories of the Information Society", New York, Routledge, 2006.

[9] Vuksanović, Dragan and Vešić, Jelena, Korčok, Davor, "Industry 4.0: the Future Concepts and New Visions of Factory of the Future Development" Researchgate, ResearchGate GmbH, 26 September 2019, https://www.researchgate.net/publication/303561107_I ndustry_40_the_Future_ConceptRXs_and_New_Vision s_of_Factory_of_the_Future_Development/.

[10] Erboz, Gizem, "How To Define Industry 4.0: Main Pillars Of Industry 4.0", Researchgate, ResearchGate $\mathrm{GmbH}, 26$ September 2019, https://www.researchgate.net/publication/326557388_H
ow_To_Define_Industry_40_Main_Pillars_Of_Industry $-40 /$.

[11] Gere. Charlie. "New Media Art and the Gallery in the Digital Age", Tate Papers, Tate, 26 September 2019, https://www.tate.org.uk/research/publications/tatepapers/02/new-media-art-and-the-gallery-in-the-digitalage/.

[12] Maulina. Rini. "Indung On Waditra Kacapi”. VISUALITA: Jurnal Online Desain Komunikasi Visual, 7(2), 45-59 (2019). DOI: https://doi.org/10.33375/vslt.v7i2.1461

[13] Heryana, Agus. "Mitologi Perempuan Sunda [Mythology of Sundanese Women]." PATANJALA: Jurnal Penelitian Sejarah dan Budaya 4.1 (2012).

[14] Maulina. Rini, Sabana. Setiawan, Damayanti. Nuning Yanti, "Indung, Penciptaan Karya Seni Berkarakteristik Seni Rupa Nusantara [Indung, The Creation of Artwork with Archipelago Fine Arts Charactheristics] .", Prosiding Seminar nasional Seni dan Desain, Reinvensi Budaya Visual Nusantara, h. 353-358, Jurusan Seni Rupa dan Jurusan Desain, Universitas Negeri Surabaya, 2019.

https://proceedings.sendesunesa.net/publications/28942 3/indung-penciptaan-karya-seni-berkarakteristik-senirupa-nusantara

[15] Toelle. Christine G, "Fungsi Sosial Seni - Kajian Teori Feldman [The Social Function of Art - Study of Feldman's Theory].” Academia.edu, Academia, 27 September 2019, https://www.academia.edu/35950418/Fungsi_Sosial_Se ni_-_Kajian_Teori_Feldman/. 